\title{
Optimizing Student Photography Skills Through Development of Project Based E-Learning in Photography Courses
}

\author{
Adrianus I Wayan Ilia Yuda Sukmana ${ }^{1 *}$, I Komang Sudarma ${ }^{1}$ \\ ${ }^{1}$ Universitas Pendidikan Ganesha, Indonesia \\ "Corresponding author. Email: aiwiy-sukmana@undiksha.ac.id
}

\begin{abstract}
Even at this time photography is becoming a trend, apparently it does not have a major impact on college students mastery of theoretical concepts in photography courses. The reality that happens is that the understanding of the basic concepts of photography is not very good, so it has implications for his skills. Based on the data obtained in the field, student learning outcomes are not satisfactory. Based on this phenomenon, development research is carried out to produce e-learning products based on project-based learning model to improve student photography learning outcomes. The development process carried out refers to the stages of the ADDIE development model which involves media experts, learning design experts, learning content experts as media validators and semester II students as research subjects. This study aims to 1 ) describe design the project based learning (PjBL) based e-learning; 2 ) Describe responses of experts and students to quality of project based learning (PjBL) Based e-learning wich had been developed; 3) To determine the effectiveness of the product (project based learning ( $\mathrm{PjBL}$ ) Based e-learning) in improving student photography learning outcomes.
\end{abstract}

Keywords: e-Learning, Project Based Learning, Photography

\section{INTRODUCTION}

Photo is a communication medium that is very commonly used to convey messages to other parties. Basically, photos are media that can be used to document an important moment [1]. London, B., et al. interpreted that photography is basically an art of visual communication [2]. In order to produce photographs that are good in conveying messages / information and are attractive in terms of artistic aesthetics, one really needs to master the basic theory and technical skills of photography.

In Educational Technology Department, photography is one of the courses offered since the establishment of this Department. Photography is one of the courses areas that is important to be mastered because it becomes the basic foundation in developing authentic and relevant learning media, especially visual media [3]. However, along the way, the quality of students learning outcomes in the field of photography has decreased. The decline in students reading interest is the main factor in the lack of learning outcomes of photography, even though photography is currently a very popular trend. This was exacerbated by the conditions in the middle of the Covid19 pandemic which caused the learning process to be not optimal, especially those that really needed understanding and practical concepts.

In the midst of the Covid-19 period like today, changes in learning patterns are very urgent to be done immediately. The reason is the situation amid the pandemic period covid-19 requires learners for learning distantly and do it at home. Due to this pandemic, students are less prepared for new learning situations. The motivation of students is decreasing in participating in learning. Students who usually participate in class learning with friends must be faced with learning situations at home so that students feel bored.

The Covid-19 pandemic currently occurring makes students have to deal with technology to support learning. Educational institutions must prepare facilities and prepare teaching materials in distance learning carefully [4]. Zapalska explains that to make online learning effective, learners need to provide various learning experiences for learners [4]. In this case the target is college students. 
The solution that can be used is develop a learning strategy that makes it easier for students to learn and explore and understand their knowledge in a broad, dynamic manner but still adhere to the principles of systematic learning. The solution is the development of e-learning based on the Project Based Learning learning model (Project based e-learning). E-learning is a learning medium which involves the use of computer and internet technology which is open distance learning (ODL). As for what is meant by Open distance learning, which is a distance learning model, where lecturers and students are not in the same place and at the same time, and do not physically meet face to face [5]. With the existence of this Project based e-learning media, students will be more flexible in accessing their learning. Students may not only study in class, but wherever and whenever they want.

Besides that, based on the PjBL learning model, the existence of e-learning is felt to be more relevant in solving student learning problems. Project Based Learning $(\mathrm{PjBL})$ is a contextual learning model through complex activities (Ellis \& Hapner, 2008; Fos et al., 2007; Grant, 2002; Turgut, 2008; Yusidere \& Turnuklu, 2006 in [6]). In Project Based Learning (PjBL), the focus of learning is the concepts and principles of a discipline of study, the involvement of learners (students) in problem-solving investigations and meaningful task activities, providing opportunities for learners (students) to work autonomously to construct their own knowledge, and reach its peak through producing real products [6].

Based on the above realities, this study was conducted to examine about the Optimizing Student Photography Skills Through Development of Project Based ELearning in Photography Courses.

\section{RESEARCH METHODS}

This research is a research and development which refers to the ADDIE development model which is structured and systematic in an effort to solve learning problems related to learning resources that are in accordance with the needs and characteristics of learners [7]. As its name implies, the ADDIE Model consists of the Analysis, Design, Development, Implementation, Evaluation stages.

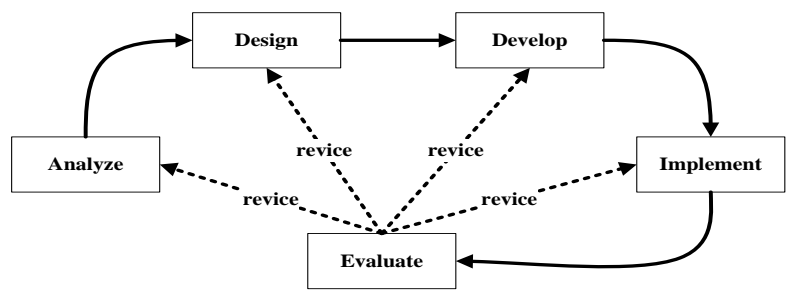

Figure 1 of ADDIE Model [8]

Each stage in the ADDIE product development model is basically connected. The dotted line shows the feedback path for making improvements based on the evaluation performed [8].

Development procedures in this study are: 1) Analysis, which focuses on curriculum analysis to measure the depth of the required material, characteristic analysis. 2) Design, aims to determine the learning experience that the learner (in this case is a student) needs to mastered during learning activities [9]. The design stage is focused on 3 activities, namely the selection of materials according to the characteristics of students and competency demands, learning strategies, assessment and evaluation methods. 3) Development, content preparation activities and creation of project based e-learning based on the design stage. 4) Implementation, carried out in 2 stages. In the first stage, a validity test was carried out by subject content experts, instructional media experts, and learning design experts. The next stage is the effectiveness testing of project based e-learning which involves a number of students as an individual group, small group students, and large groups to do test for effectiveness of the products that have been developed. 5) Evaluation, evaluation is carried out through formative evaluation and summative evaluation. The formative evaluation stage is carried out to collect data at each stage used to improve e-learning that has been developed, while summative evaluation is carried out at the end of the development process to measure the effectiveness of this product on student learning outcomes.

Research subjects: 3 college students as individual test subjects, 9 students as small group subjects. The last stage is the field test (product effectiveness test), the research subjects at this stage were 44 students who took Photography courses.

Student learning outcomes data were analyzed using nonparametric statistics with the Wilcoxon signed-rank test method. The research hypotheses tested are as follows:

$\mathrm{H0}$ : There are no significant difference in student learning outcomes before using project based e-learning and after using project based e-learning.

H1 : There are significant difference in student learning outcomes before using project based e-learning and after using project based e-learning.

\section{RESULTS AND DISCUSSION RESULTS}

Based on the development stage by referring to the ADDIE development model, The Project Based Elearning was successfully developed. The Project Based E-learning was developed using the main Learning Management System (LMS) software, namely Moodle. The following are some views of The Project Based Elearning that have been developed. 


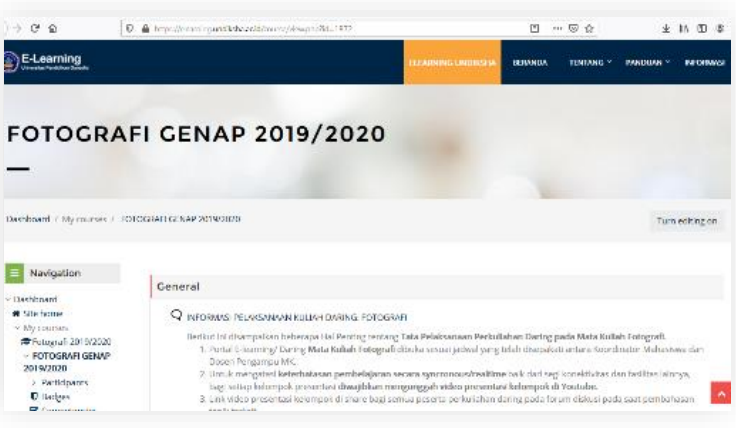

Figure 2 Views of The Project Based E-learning Page

At the beginning of the page contains information about the course administration on this e-learning based project portal. It also contains information on the selection of class groups so that administrative tasks are easy to manage.

Next is a content page that displays the content structure developed based on the project-based learning model procedures that have been established at the design stage. This content page is equipped with presentation, discussion and final product upload activities
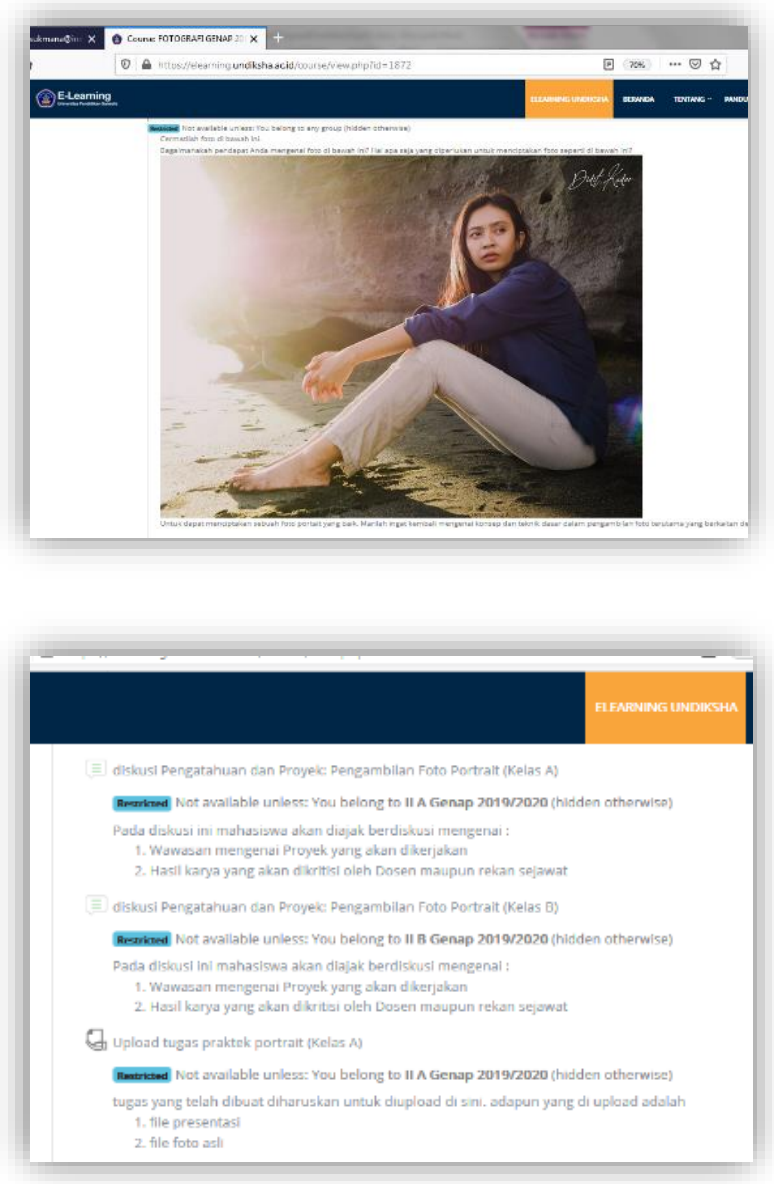

Figure 3 Views of Lecturer Topic Page
After the product passes the development stage, the next stage is the implementation stage. In the implementation stage, 2 testing stages are carried out, namely the validation test and the Usability Test. The validation test is viewed from 3 aspects, namely content aspects, learning design and media aspects. The results of the content validation test obtained a score of $95.38 \%$ (in the Very Good category), while from the aspect of learning design, the mean score reached $95.7 \%$ (Very Good category) and the last one was the result of the validation test for the media aspect with a score of $97.33 \%$. (Very good category). The next stage is the usability test which consists of individual trials and small group trials. The individual test results obtained a score of $95 \%$ (very good category) and from the small group test results obtained a score of $92.92 \%$ which is in the very good category. After the above steps have been passed, the last one is the product effectiveness test. The subjects of this effectiveness test were 44 college students. The results of the effectiveness test analysis using the Wilcoxon test method can be seen as below.

Table 1. Test Statistics Wilcoxon Signed Ranks Test

\begin{tabular}{|l|r|}
\hline & \multicolumn{1}{|c|}{ Post - Pre } \\
\hline$Z$ & $-5.493^{\mathrm{a}}$ \\
\hline Asymp. Sig. (2-tailed) & .000 \\
\hline
\end{tabular}

Based on the output "test statistics" above, it can be seen that Asymp. Sig. (2-tailed) is worth 0.000 (value $0.000<0.05)$ so it can be stated that "H1 is accepted". Thus, it can be interpreted that there are significant differences in student learning outcomes before using project based e-learning and after using project based elearning. From these findings, it can be concluded that "Project based E-learning are effective in improving student learning outcomes in Department of Educational Technology of IPPB FIP Undiksha in photography courses" in other word, the development of Project Based E-Learning in Photography Courses has succeeded in optimizing students' photography skills.

\section{DISCUSSION}

E-learning has provided revolutionary changes in the world of education, from learning methods, learning processes to learning media from conventional to more modern forms. In its journey, e-learning is applied by various universities due to various reasons, including: (1) learning in college is theoretically more andragogy (adult education) than pedagogy. Adults have more extrinsic motivation towards their information and knowledge needs; (2) encouraging learning that results in higher levels of learner involvement; (3) motivating students to interact, exchange information, respect different points of view, facilitate communication and improve relationships that support learning; (4) e-learning is a need for students who have been familiar with using 
advanced technology and flexibility in where and how they study [10].

In this regard, based on the product effectiveness test, it is proven that "Project Based E-Learning is effective in improving student learning outcomes of the Department of Educational Technology of IPPB FIP Undiksha in the photography course", in other words the development of Project Based E-Learning is proven to be able to optimize knowledge and student skills in photography courses. There are several things that cause the effectiveness of this e-learning product in improving student learning outcomes of the Department of Educational Technology of IPPB FIP Undiksha in the photography course. One of them is the quality of the course material. The material in the project based e-learning is very well qualified, in other words, the learning content developed is in accordance with the demands of the curriculum which is reflected in Competency Standards, Basic Competencies, Indicators to learning objectives. In this regard, [11] emphasizes that mapping and organizing of learning materials is very important as an effort to determine and classify learning materials into subjects, sub-subjects, so that they are in accordance with predetermined learning outcomes. Besides that, the quality of the learning material is also determined by the accuracy of the language in the delivery of the material. This is because learning is basically a systematic design that is communicated through language to students, so that students carry out learning activities in achieving the desired goals [12]. Judging from the definition of learning as a communication pattern in this statement, it is clear that the use of appropriate language and in accordance with the characteristics of students will greatly affect the effectiveness of communicating to convey learning messages. The better the language used, the more effective the delivery of learning messages, in this case, is the photography learning material.

In addition to good material packaging, the quality of a good learning media is determined by the quality of the learning design embedded in it. The clarity of the learning design and the existence of step directions in learning greatly assist students in carrying out learning through this project-based e-learning. In this e-learning, students are facilitated with learning settings that accommodate independence and flexibility in carrying out their learning. The learning setting is synchronous and asynchronous learning. Besides, the adaptation of the Project Based Learning learning model which is embedded in this e-learning is very important for the learning process that occurs.

Project-based learning is a model that focuses on creative thinking, problem solving, and interactions between students to create and use new knowledge, especially in the context of active learning [13]. In its implementation of problem based e-learning, this learning model is transformed into (1) a set of specific learning objectives and key concepts, (2) a project description with its rationalization, (3) a list of materials and resources, (4) a set of tasks in project completion, and (5) assessment criteria and project appraisal rubric. This refers to the description of Roessingh and Chambers (2011, p.60), which said that an important element in project design, namely, (1) a set of specific learning objectives and key concepts, (2) a project description with its rationalization, (3) a list of materials. and resources, (4) enabling a set of tasks, and (5) assessment criteria and rubrics [13].

There are at least 2 things that need to be considered after implementing learning using this project based elearning. First, there is a change in Students' Creative Thinking Abilities. This is because in this project based e-learning, learning is designed so that students are able to formulate learning goals and targets and organize their own learning activities according to the project targets given. Based on this, students through their creativity build knowledge based on learning experiences and interactions with other students. In relation to these findings, Jussoft et al. stated that $\mathrm{PjBL}$ learning accustoms students to be more disciplined and systematic in solving problems. Students are required to produce projects where the project requires creativity from the knowledge they have through collaborative activities with group members so that this motivates them to solve problems or assign tasks. So, this model directly requires the creativity of students in solving the problems received [14].

Second, increasing students' Self Regulated Learning. With the application of online learning using project based e-learning in the midst of the Covid-19 pandemic, students inevitably have to learn independently. This trains students' independence in managing their own learning by arranging their learning strategies. In this regard, Sudianto, Dwijanto, N.R., \& Dewi, explained that students who carry out online learning with the PjBL learning model appear to be more independent in doing assignments and in the learning process. This shows that online learning with the PjBL learning model provides a high contribution to student learning independence [14].

\section{CONCLUSION}

E-learning is a revolutionary breakthrough in the world of education, starting from learning methods, learning processes to learning media from conventional to more modern forms. Based on the studies that have been conducted, the development of Project Based eLearning has proven to be able to optimize students' knowledge and skills in photography courses. This is due to several things, namely the quality of the material presented. Apart from the well-packaged material, this is also influenced by the quality of the learning design embedded in it. The learning design that adapts the PjBL 
learning model plays an important role in the learning process that occurs through e-learning.

There are at least 2 things that need to be considered after the application of learning using this project based e-learning. First, there is a change in Students 'Creative Thinking Abilities and secondly, learning using projectbased e-learning is able to increase students' Self Regulated Learning.

\section{REFERENCES}

[1] K. Sudarma, Fotografi, Yogyakarta: Graha Ilmu, 2014

[2] A. G. Belal, Photography, (bahan ajar): Helwan University, 2019.

[3] I. K. Sudarma, Silabus Mata kuliah: Fotografi, Singaraja, 2017.

[4] Mastura and R. Santaria, Dampak Pandemi Covid19 terhadap Proses Pengajaran bagi Guru dan Siswa, Jurnal Studi Guru dan Pembelajaran, Vol. 3(2), 2020, pp. 289-295.

[5] Sucipto, Peningkatan Self Regulated Learning Mahasiswa di Era Digital, SoulMath, Vol. 5 No. 1, 2017, pp. 31-41.

[6] I. W. Santyasa, Pembelajaran Inovatif, Singaraja: Undiksha Press, 2011.

[7] I. M. Tegeh and I. M. Kirna, Pengembangan bahan ajar metode penelitian pengembangan pendidikan dengan ADDIE model, Universitas Pendidikan Ganesha, Laporan Penelitian, Unpublished, Singaraja, 2010.

[8] R. Gagne, W. Wager, K. Golas and J. Keller, Principles of instructional design, 5th Ed., Belmont, CA: Wadsworth/Thomson Learning, 2005.

[9] B. A. Pribadi, Model desain sistem pembelajaran, Jakarta: Dian Rakyat, 2009.

[10] R. Rivalina, Strategi Pemanfaatan E-Learning Dalam Mengatasi Keterbatasan Jumlah Dosen, Kwangsan, Vol. 5, No. 2, , 2017, pp. 129 - 145.

[11] U. A. Chaeruman, Pedati Model Desain Sistem Pembelajaran Blended, Jakarta, 2018.

[12] L. Wicaksono, Bahasa Dalam Komunikasi Pembelajaran, Jurnal Pembelajaran Prospektif, 2016, pp. 9-19.

[13] F. Wajdi, Implementasi Project Based Learning (PBL) dan Penilaian Autentik Dalam Pembelajaran Drama Indonesia, Jurnal Pendidikan Bahasa dan Sastra, 2017, pp. 81-97.

[14] Sudianto, N. R. Dwijanto, and Dewi, Students' Creative Thinking Abilities and Self Regulated
Learning on Project-Based Learning with LMS Moodle, Unnes Journal of Mathematics Education Research, Vol. 8 No.1, 2019, pp. 10-17. 